\title{
パッケージ技術のシステム実装化への展望
}

\section{Future Prospect of System Jisso Technology Progress in Electronic Packaging}

\author{
システムインテグレーション実装技術委員会
}

\section{1. はじめに}

2020 年に東京オリンピックが開催される。折しもその決 定直前に, HOT CHIPS 25 の基調講演において DARPAのコ ルウェル氏が, ムーアの法則は「早くて 2020 年に終わりを 迎える」と発表したことが話題になった。昨年同時期のIDF (Intel Developer Forum) 2012 において, ムーアの法則は「少 なくとも今後 10 年は続く」とボーア氏が述べてから 1 年足 らずであり，また物理限界も近いということもあって関心 が高かった。一方, システム（セット）製品においてはイ ンターネット技術および通信技術の発展により，ますます 新しいアプリケーションが広がっており, エレクトロニク ス技術全体に対してはこれらを達成するための性能向上や 新しい機能の実現がさらに期待されている。このような状 況において実装技術の役割がますます重要になってきてい る。

実装技術はこれまで日本が世界をリードしてきたにもか かわらず，昨今では実装階層に基づく水平分業による国外 製造の影響により, 個々の階層での技術開発が海外勢に押 されている。JEITA では実装技術を広義に捉えた「Jisso 技 術」として, 材料・部品などにおける各固有技術を横断的 かつ有機的に結び付けた統合設計技術という概念を提示し ている1)。これはもちろん, パターン設計のみではなく, いうなれば実装設計であり，市場から「なにを」求められ ているかをつかみ, それを「どのように」達成するかに落 とし込む技術とも言える。実装階層を横断的かつ有機的に 結び付けるのは日本が得意とするところであり, 半導体微 細化の 2020 年課題と東京オリンピック開催も何かしらの縁 とも思われる。システムインテグレーション実装技術委員 会ではまさにこの領域も含めて議論しており, 本稿では特 に注目されているパッケージング技術について解説すると ともに，今後の展望について述べる。

\section{2. ウェーハレベル・パッケージング技術}

ベアチップ実装での KGD (Known Good Die) 問題を解決 する手段の 1 つとして 1990 年度後半に実用化された WL-
CSP (Wafer Level Chip Size Package) は，モバイル機器など で用途が飛躍的に増大している。デバイスが形成された ウェーハ上に, 再配線層およびデバイス表面保護部と外部 I/O 端子を形成し，最後にダイシングによる個片化でパッ ケージが完成する。従来はパッケージ基体に，個々にベア チップを実装するのが通常であったが, ウェーハ上のデバ イスを一括でパッケージ化することと使用材料を減らすこ とが可能なために，半導体パッケージとしての低コスト化 が期待できる。半導体前工程と後工程の融合技術とも言え る。当初の WL-CSP は数〜数十ピンのロジックやメモリで 適用され，サイズも有機配線板との熱膨張差の問題で $7 \mathrm{~mm}$ 角以下の小さい部品であったが，現在では端子ピッチも 0.4 $\mathrm{mm}$ ピッチ, さらには $0.3 \mathrm{~mm}$ ピッチが適用でき, サイズも $7 \mathrm{~mm}$ を超え, ピン数も数百ピンのパッケージにも対応で きる技術となっている。将来は端子数が千ピンを超えるデ バイスでもウェーハレベルでパッケージ化できる可能性が ある ${ }^{2)}$ 。現状の WL-CSP としては，デバイス単体でのパッ ケージがほとんどではあるが, 次項の三次元化集積技術で のサプライチェーンの課題（デバイス保証）に対する 1 つ の解決策になるかもしれない。

WL-CSP の多くは半導体前工程後のウェー八を使用した ファンイン型（チップサイズ内で I/O 端子が構成される） のパッケージであり, ウェーハ上でのデバイス歩留りが高 いことも必要条件となっている。一方, このチップ歩留り への対応と, 配線板への接続ピッチを考慮した多ピンデバ イスのために, ファンアウト型の WL-CSP も開発されてい る。図 1 に製造工程の概要を示す。良品チップを微細配線 層が形成されたウェーハにフリップチップ実装し，樹脂で 埋め, 配線層を残して基材ウェーハを除去した後にパッ ケージ個片化する方法や, ガラスなどのサポートウェーハ に良品チップをフェースダウンで整列配置して樹脂で埋 め, サポートウェーハを取り除いたチップ表面に微細配線 層を形成する方法などがある。しかし，デバイス単体での ファンアウト型 WL-CSP は，前述のファンイン型パッケー ジでの I/O 端子の狭ピッチ化や, フリップチップ BGAパッ ケージにおけるパッケージ基板のパターンファイン化（コ 


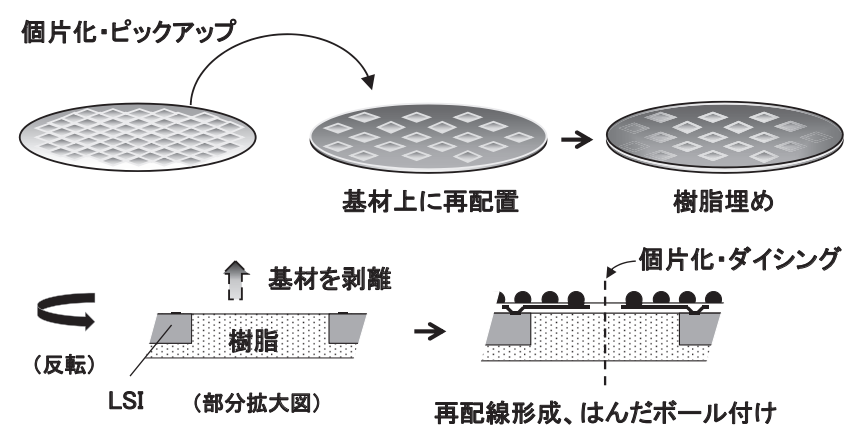

図 1. ファンアウト型ウェーハレベル・パッケージング例

アレス基板など）と競合する可能性もあり，これらを見据 えた適用領域を選定しての開発が必要となる。

ここで，デバイス単体ではなく複数種類のデバイスを集 積し, 擬似 SoC (Pseudo System on Chip) と呼ぶ構造も提案 されている3)。SoC はマイクロプロセッサやコントローラ, メモリなどの機能回路を 1 つのデバイスチップ内に集積し たものであるが, 擬似 SoCでは, 前記のファンアウト型 WL-CSP 技術により複数種類のデバイスをワンパッケージ 化し，あたかも 1 つのデバイスチップに見てとれる形状と なっている。開発費が膨大となる $\mathrm{SoC}$ の問題を解決し, MEMS などの異種デバイスも混載可能な技術となってい る。また, 製造工程ではウェー八形状であるために, 半導 体製造装置を転用して微細な配線網が形成できるという特 長もある。生産量が見込めないと新規なデバイスは開発で きない現状にとって，必要となる既存あるいは安価なデバ イスを集積することで, 容易に求められる機能を達成する 技術としても有効と考えられる。

ウェーハレベル・パッケージング技術は, パッケージ基 板を使用しないことで低コスト化を狙う技術でもある。し かし, 特にファンイン型のパッケージサイズ（デバイスサ イズ）は, 前述した $7 \mathrm{~mm}$ 角を超えても $20 \mathrm{~mm}$ 角程度まで となるであろう。これは, ワークサイズであるウェーハの 大きさによるものであり, 多数個取りで一括形成する利点 を享受できる範囲に制限されると考えられるためである。

\section{3. 三次元化技術}

最近では, TSV (Through Silicon Via)を使用した三次元積 層デバイスの開発話題が盛況である。しかし, 高集積化・ 高機能化を狙う三次元化実装技術は, この三次元積層デバ イス技術だけではない。すでに実用化されている三次元化 技術の一例を図 2 に示す。これらの技術が将来, 三次元積 層デバイス技術で置き換わるということは無く, 要求され る機能, 性能, そしてコストによって選択され, あるいは 適材適所で混在し，さらには新規な融合技術が生まれる可 能性もある。今後ますます実装設計が重要になってくるこ とは言うまでもない。ここでは, 三次元積層デバイス技術 のほか, これから期待される三次元化技術についても述べ

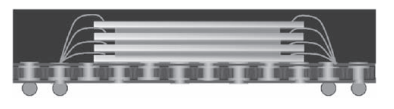

(a) チップスタック型MCP (Multi Chip Package)

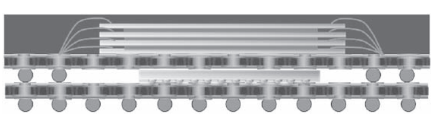

(b) PoP (Package on Package)

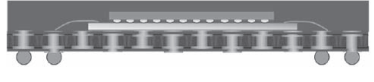

(c) $\mathrm{CoC}$ (Chip on Chip)
図 2. 実用化されている三次元化パッケージ技術の例

ていく。

\section{1 三次元 (3D) 積層デバイス}

「なぜに TSV なのか」と問われた場合，小型化は勿論で はあるが，一言で言えば「電気的な特性要求を達成するた め」である。現状でも $\mathrm{CPU}$ 処理能力の向上にデバイス間の デー夕転送速度が追いつけず，それがシステム性能を律速 している。モバイル系でも CPU とメモリ間のデー夕転送速 度がすでに $10 \mathrm{~GB} / \mathrm{s}$ を超えて, さらにこの先にも倍々での 性能向上が望まれている。例えば， $5 \mathrm{GHz}$ の高速信号で は, その配線長が約 $1.5 \mathrm{~cm}$ 以上になると分布定数線路とし ての構成㧍よび取り扱いが必要となってくるため, 集中定 数線路としてデバイス間相互接続を行うにはこれ以下にす る必要がある。とにもかくにも, デバイス間接続は短けれ ば短いほど良い。電源系も同じである。また，配線接続長 が短くなればその駆動能力も小さくすることができ，消費 電力の低減にもつながる。一方, デー夕転送速度の向上に ともない,メモリ自体の容量も増大することが必要とな る。TSVによる 3D 積層デバイスは，これらを踏まえての 解決策である。

データ転送速度（バンド幅）は，信号伝送速度と信号 （配線）数との掛算であるので, 信号数を大幅に増やして信 号伝送速度は従来と同等という形式でモバイル系に規格化 されたのが Wide I/O の JEDEC 規格である。TSVを使用す ることを前提にして㧍り, バス幅 512 ビットと従来の8〜 16 倍にした一方で動作周波数は $200 \mathrm{MHz}$ と低速にしてい る。I/O 端子は, 1 チャンネルが 6 列 50 行（各 $40 \mu \mathrm{m}, 50$ $\mu \mathrm{m}$ ピッチ）で構成され，4 チャンネルで 1,200 ピンの $\mathrm{I} / \mathrm{O}$ 構成となっている。2013〜2014 年での量産化が期待された が, 従来の PoP 構造での LPDDR3 が同等性能を達成できる ことになったこともあり使用されなかった。これは，主に 3D 積層にかかわる製造コスト（TSV 形成や微細接続実装） に加えて, 個々のデバイスチップ歩留りによる損失を含む) の要因が大きい ${ }^{4)}$ 。また, CPU ( $\left.\mathrm{SoC}\right)$ 上にメモリを積層す るために, サプライチェーン上の保証の問題もある。

一方, Micron Technology 社から HMC (Hybrid Memory Cube) と呼ばれる DRAM の ES サンプル出荷を開始すると のニュースリリースがあった（詳細は参考文献を参照） 5)。 HMC は, ハイエンド向けにメモリ機能に特化し, 複数メモ リ間およびコントローラを TSV 接続で積層実装する技術が 
使用されている。別に配置された CPU (SoC) とのデータ転 送接続は高速シリアル伝送が基本となっており, メイン基 板（あるいはインターポーザ）に HMC と CPU (SoC) を実 装し，分布定数線路による相互接続となる。

TSV 技術はすでにCMOS イメージセンサで実用化されて いるが，いよいよ次は積層メモリでの実用化が始まろうと している。前述の HMC は, まずはハイエンド市場向けか らの採用を目論んでいる。一方, モバイル機器など民生用 機器での必要性能も現状技術では難しさを増しており，3D 積層デバイスは特にメモリなどの同種複数チップ使用の場 合に今後必要になってくるであろう。このための技術課題 として低コスト化は必須であり, 製造プロセス技術および 検査技術を含めたインフラ装置開発, 接続材料および積層 間の封止材料開発などがさらに必要となる。TSV 形成は半 導体前工程での技術であるが, チップ積層にかかわるこれ らの実装技術が半導体前工程にも展開されつつある。ま た, 合わせて開発される個々の要素技術は, 後工程での技 術開発にも応用されていくであろう。

\section{$3.22 .5 \mathrm{D}$ デバイス実装}

ウェーハに配線層のみが形成されたシリコン・インター ポーザにデバイスを実装する構造も提案されている。イン ターポーザには半導体素子が形成されていない積層構造で もあるので $2.5 \mathrm{D}$ と呼称される。インターポーザ上に実装さ れるデバイスは平置き (Side by Side) で, すでにXilinx 社が FPGA で実用化している。FPGA の大規模化に伴ってチッ プサイズが大きくなり歩留りが悪化することを補うため に，グローバル配線層を形成したインターポーザを利用 し，デバイスは歩留りの良いサイズで製造する方式をとっ ている。従来の MCM (Multi Chip Module) と構造上は同じ ではあるが, $1 \mu \mathrm{m}$ 程度の非常に微細な配線網が形成できる ことが特長である。デバイスの三次元実装とは厳密には言 えないかもしれないが, インターポーザに薄膜素子や半導 体素子の形成も可能であるため, また図 3 に示すように, $3 \mathrm{D}$ 積層デバイスを実装する基板としても有効であるために ここで取り上げる。

$2.5 \mathrm{D}$ 実装ではインターポーザ技術がカギを握っている。 層間接続を含む微細配線網の形成が必要になり, 前述のシ リコン・インターポーザでは層間絶縁材料に無機絶縁材料 $\left(\mathrm{SiO}_{2}\right)$ が用いられ，その他にも BCB (Benzo- cyclobuten) や ポリイミドなどの有機材料を使用する例（図 4）もある。 $3 \mathrm{D}$ 積層デバイスでは，デバイスの厚みを薄くすることで TSV 形成を容易にしているが, インターポーザでは基材と しての構造確保のために厚みが必要なことから, 高アスペ クト比の TSVが必要となる。また, 3D 積層技術で異なる 種類のデバイスを集積する場合には，デバイス保証とサプ ライチェーンの課題があるが，2.5D 実装ではその軽減が期 待でき, システム化を狙う場合には重要な技術となる。

従来のパッケージ基板では困難であった微細配線を薄膜

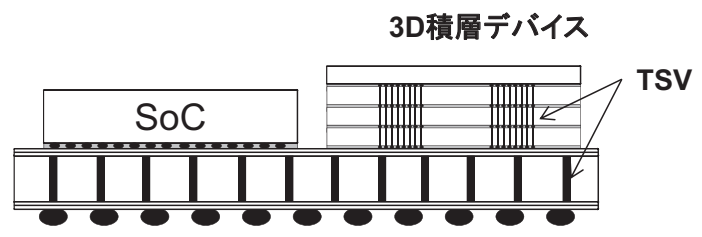

図 3. 三次元 (3D) 積層デバイスと 2.5D デバイス実装（断 面イメージ)

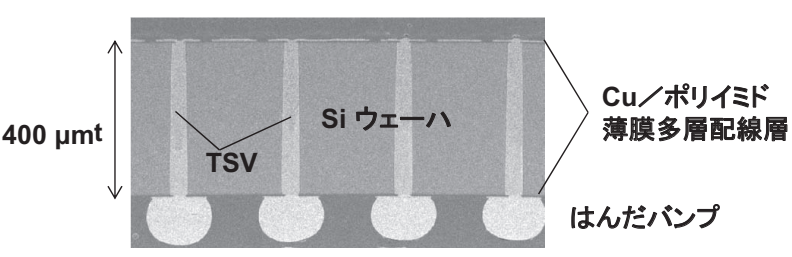

図 4. TSV 付きシリコン・インターポーザの断面写真

技術で達成したシリコン・インターポーザではあるが，ま だコストが高くアプリケーションは限られる。もちろん， シリコン・インターポーザの低コスト化の開発は進められ ているが, 低コスト化に向けて基材に無アルカリガラスな どを使用したガラス・インターポーザも開発されている。 シリコンはウェーハサイズで形成個数が限定されるが，ガ ラスでは液晶ディスプレイの製造設備などを流用してワー クサイズを大きくし，一括製造の個数増により低コスト化 をはかることが可能である。一方，シリコンと違ってガラ スに高アスペクト比の貫通ビアを開けるのは難しい。最近 ではレーザーや電気放電加工による穴あけ技術も開発され ている。

また，従来のパッケージ基板で使用されてきた有機材料 でも，配線の微細化開発が進んでいる。従来技術での課題 は，有機材料と配線導体である銅との密着，およびデバイ ス構成材料であるシリコンと有機材料との熱膨張係数差で あった。特に前者では，有機材料表面改質や接着プロモー 夕材料によって，ロー・プロファイルあるいは平滑銅䇴を 使用してパターン形成精度の向上による配線微細化技術が 開発されている。また, 導体層形成や層間接続ビア形成に 薄膜技術（いわゆる半導体ドライプロセス）を併用する例 もある。これらによって, 有機基板でも数 $\mu \mathrm{m}$ の配線幅, 数十 $\mu \mathrm{m}$ ピッチの層間接続ビアも可能になりつつある。

\section{3 部品内蔵技術}

部品内蔵技術は，さらなる小型化・高機能化などに対応 するためのポストSMTの一役を担う技術として注目され 市場に浸透してきている。この技術を用いた製品はまだ配 線板の一種として扱われることが多いが，実装技術からみ たその潜在性や技術的要因からモジュールとして捉えるべ きであり，さらには次世代 PoP としてのパッケージ技術で あるとも言える ${ }^{6}$ 。従来製品が配線板内に受動部品を内蔵 することが多かったが, 最近では半導体デバイスなどの能 動部品を内蔵した製品も多くなってきている。部品内蔵技 


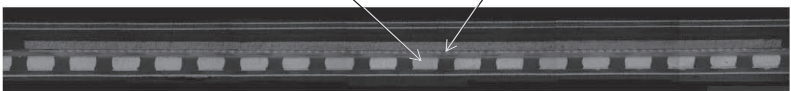

図 5. デバイス内蔵パッケージの例 $(7.3 \mathrm{~mm}$ 角 400 ピン・ チップ)

術は, 半導体後工程から, いわゆる部品となるモジュール までの実装階層における技術を有機的に結合し, 最適化で きる技術となりうる。また, 配線板技術とデバイス実装技 術を融合した技術であり，配線板技術によってデバイスの 三次元実装を達成できる技術となる。一方, 三次元化実装 において，デバイス自体の三次元化の次に必要になるのは デバイス間配線網の三次元化である。TSV 技術はデバイス 内での垂直方向の配線形成であり, 部品内蔵技術はデバイ ス外においてデバイスを跨ぐ形で垂直方向にランダム配線 形成を達成することができる。

安価な製造工程中に高価なデバイスを内蔵することはで きないと配線板メーカからの話を聞いたことがある。しか し半導体後工程では, 樹脂モールドを含めて工法は異なる ものの, 従来から普通に行ってきたことである。主にはデ バイスの取扱いやノウハウが足りないためと思われるが, 検査・分析・評価技術が無いことがその要因であろう。こ れらの技術を保有することができれば，パッケージ部品と しての製品化も可能であり, 部品内蔵技術もパッケージン グ技術の 1 つなることができる。チップスタック技術や 前述の $3 \mathrm{D}$ 積層デバイス技術において, デバイス薄化技術 が進展している。配線板における絶縁層 1２層の厚みに内 蔵できるので, $0.5 \mathrm{~mm}$ 以下の厚み（ちょっとした厚紙の厚 さ）のパッケージも実現可能と思われる。また, 前項の微 細配線を有する有機インターポーザ技術も取り入れれば, 多ピンデバイスのパッケージにも適用が可能となる。

もちろん, 異種デバイスや特に受動部品の混載が容易で あることは, システムを構成するために非常に有効とな る。ただし，すべての部品を配線板内に内蔵することは意 味がなく, 回路構成や部品特性, そして性能を踏まえた実 装設計が重要となる。

\section{4. 今後のパッケージ技術の進展}

生産量が期待できなければ, 新規の SoC や ASIC が開発 できなくなってきている。そのため, 今後ますます $\mathrm{SiP} や$ MCM が重要になってくると思われる。ただし, 従来はモ ジュールという形態であったが, 本稿で述べてきた集積化 技術でもわかるように, 構成上はモジュールであっても外 観上はパッケージそのものとなりつつある7)。コモディ ティ化が進む半導体デバイスと差別化デバイスを含有する システムパッケージが, 使い易さという点をもって数多く 世に出てくると思われる。水平分業体制を活かし, かつ, それらを融合する技術が今後重要になってくる。
一方で，低コスト化につながるモノづくりのシンプルさ （容易さではない）も重要になると考えられる。フリップ チップ実装は端子接続を一括で行う技術として古くから知 られているが，民生用にも広く使用されるようになったの は近年のことである。一方, デバイス単体のパッケージン グは，まだ 1 個 1 個精度良くマウントすることが必要とさ れている。半導体デバイスをセルフアラインで実装する技 術も開発されており ${ }^{8)}$, パッケージ化と相まって, 多数個 取り（数百〜数千）された状態での一括接続技術および一 括配線形成技術が期待される。

また，三次元集積化技術を含む集積化技術において，特 に設計技術と検査技術にはまだまだ課題がある。半導体設 計ツール，配線板設計ツール，構造設計ツールなどそれぞ れあるが，システム化されたパッケージではこれらを統合 設計する必要がある。開発費となる設計費が増大してし まっては，ある意味 SoC と同じくアプリケーションが限定 されてしまう。適材適所での設計効率化が必要になる。さ らには,この統合設計のもとで検査技術は, どの段階で何 を検査するのかをもう一度見直す必要がある。三次元積層 デバイスなど，端子接続ピッチが狭ピッチになると容易に は検査ができないこともある。検査コストは, 製品 1 つ 1 つに確実に生じてくるので非常に重要になる。バウンダリ スキャンテスト (IEEE 1149.1) などのテスト容易化技術の適 用が進むものと思われる。バウンダリスキャンテストは, あらかじめデバイスの個々の I/O 回路部分にテスト用回路 (スキャンセル・スキャンパス) を追加し，それらをシリア ル接続して, わずか 4 ピン（信号 2, 制御 2）の追加端子で I/O 端子の状態を調べるテストであり，また一方ではデバ イス内部回路に影響を与えずに I/O 端子の状態を自由に設 定することもできる（外部接続される他のデバイスのテス 卜も可能)。

\section{5. おわりに}

本稿では，パッケージ技術に関連して注目される技術に ついてその概要を述べた。これらの技術は今後さらに低コ スト化に向けての開発が進んでいくであろう。また, これ らの技術を融合した技術開発も進むものと思われる。ます ます複雑化する実装形態の中で, システムインテグレー ション実装技術委員会の活動がその一助になれば幸いであ る。

文責・島田 修/大日本印刷 (2013.10.28- 受理)

\section{文献}

1)（編）実装技術ロードマップ実行委員会：“2013 年度版 日 本実装技術ロードマップ, ” p. 8，電子情報技術産業協会 (JEITA) Jisso 技術ロードマップ専門委員会, 2013 年 6 月

2)（編）実装技術ロードマップ実行委員会：“2013 年度版 日 
本実装技術ロードマップ, ” p. 140, 電子情報技術産業協会 (JEITA) Jisso 技術ロードマップ専門委員会, 2013 年 6 月

3) H. Yamada, et al.: "A Wafer-level System Integration Technology Incorporates Heterogeneous Devices,” IMAPS, pp. 793-800, September 2012

4) 木村雅秀：“3 次元 LSI は消えたのか 民生への活用シナリ オを探る,”日経エレクトロニクス，No. 1117,pp. 35-51， 2013 年 9 月 16 日号

5) Micron Technology, Inc.,: “Micron Technology Ships First Samples of Hybrid Memory Cube,”ニュースリリース, 2013 年 9 月 25 日

6) 島田 修, 他：“部品内蔵技術を用いた小型三次元モジュー ル, ”エレクトロニクス実装学会第 24 回講演大会, pp.
344-345, March 2010

7) Y. Katsuhara, et al.:"Novel GPS SiP Module with Miniaturized Substrate by using RF Sub-Circuit Embedding Technology," ICEP, pp. 221-226, April 2013

8) T. Fukushima, et al.: "Self-Assembly Process for Chip-to-Wafer Three-Dimensional Integration,” ECTC, pp. 836-841, May 2007

島田 修（しまだ おさむ）

著者紹介

1983 年 東京理科大学・理学部卒。同年東京芝浦電気 (株) (現 (株) 東芝）入社。大日本印刷（株）との合弁会社を経て 2005 年大日本印刷 (株) 入社。

現在, 高集積モジュール製品の開発・設計に従事。エレクトロニクス実 装学会, 応用物理学会, 電子情報通信学会, 次世代センサ協議会, IMAPS 各会員。JEITA・Jisso 技術ロードマップ専門委員会委員。 